\title{
Effects of Cow Dung Treated to Various Management Practices and Nitrogen Levels on Maize Grain Yield in the Northern Guinea Savanna of Nigeria
}

\author{
Joseph Tanimu ${ }^{1}$, Edward O. Uyovbisere ${ }^{2}$, Sunday W. J. Lyocks ${ }^{1}$, Yahuza Tanimu ${ }^{3} \&$ Michael O. Ayorinde $^{4}$ \\ ${ }^{1}$ Samaru College of Agriculture, Division of Agricultural Colleges, Ahmadu Bello University, Zaria, Nigeria \\ ${ }^{2}$ Soil Science Department, Institute for Agricultural Research/Faculty of Agriculture, Ahmadu Bello University, \\ Zaria, Nigeria \\ ${ }^{3}$ Department of Biological Sciences, Ahmadu Bello University, Zaria, Nigeria \\ ${ }^{4}$ Department of Vocational and Technical Education, (Agric Section), Ahmadu Bello University, Zaria, Nigeria \\ Correspondence: Joseph Tanimu, Samaru College of Agriculture, Division of Agricultural Colleges, Ahmadu \\ Bello University, Zaria, Nigeria. Tel: 234-803-703-9756. E-mail: joseph.tanimu@yahoo.com
}

\author{
Received: December 3, 2012 Accepted: February 28, 2013 Online Published: April 15, 2013 \\ doi:10.5539/jas.v5n5p226 URL: http://dx.doi.org/10.5539/jas.v5n5p226
}

\begin{abstract}
This study consisted of collection and incubation of cow dung, followed by evaluation of the incubated cow dung in field experiments in years 2003 to 2004 at the Institute of Agricultural Research, Ahmadu Bello University and Samaru College of Agriculture farms, all located in Samaru, Zaria. The objectives of this study are to determine the effects of subjecting cow dung to different management practices and nitrogen fertilizer on maize grain yield. The study was a factorial experiment, with 3 cow dung management practices, 4 storage durations in the field and 2 levels of nitrogen. There was a control treatment, where no cow dung or nitrogen fertilizer was applied. These gave a total of 25 treatment combinations, laid out in a randomized complete block design, replicated three times. The results showed that, the best cow dung management practice that gave the highest maize grain yields in the two farms was the surface heaped covered in April, nitrogen amended treatment. The non $\mathrm{N}$ amended treatments were not able to significantly increase the maize grain yields than the untreated control.
\end{abstract}

Keywords: cow dung, management practices, urea fertilizer, maize, yield, northern guinea savanna and Nigeria

\section{Introduction}

Maize is the third most important cereal crop in the world after rice and wheat (Food Agricultural Organization [FAO], 1997), and the second most important cereal crop in the farming systems of the Guinea savanna of Nigeria (Tarfa et al., 2003). Among these three crops, maize have been found to have the highest average yield per hectare and a good source of energy for human and animal and has been discovered to be very easy to process and readily digestible (Okoruwa \& Kling, 1996). In Nigeria, maize is a very important cereal crop in the farming systems of the Guinea savanna and about 4.5 million tones was produced in the country from 3.5 million hectares of land in 1983 with the Guinea savanna accounting for 70 percent of this total production (Enwenzor et al., 1989). In 1984, land area under maize cultivation in Nigeria was estimated to be about 653,000 ha and it rose to about $5.4 \mathrm{~m}$ ha in 1994 and lately decreased to $4.5 \mathrm{~m}$ ha in 2004 (Federal Ministry of Agriculture [FMA], 2005). A number of factors could have been responsible for the decrease in production and productivity.

The moist savanna (Guinea savanna) region of sub-Sahara Africa (SSA) with $42 \%$ of the SSA human population has been recognized to have the potential for increased crop and livestock production (McIntire, Bourzart, \& Pingali, 1992; Winrock, 1992; Jabbar, 1996). Increasing agricultural productivity in the region without due attention to natural resource management or the fragile soil resource of the region could impose negative consequences. It is estimated that as much as $85 \%$ of the land in this region is threatened by degradation (International Food Policy Research Institute [IFPRI], 1995).

The current global drive for sustainable agricultural systems that optimize use of low inputs, require close monitoring of soil quality (FAO, 1989). To achieve this, integrated soil fertility management systems, by combining the use of chemical amendment, biological and local organic resources, such as crop residues, green 
manure, biological N- fixation and agro-forestry for low activity clays of the savanna soil have been suggested (Kang \& Wilson, 1987). The critical factor for the success of improved farming systems seem to be the efficient recycling of organic materials (Kang \& Duguma, 1985).

The recent increases in cost of inorganic fertilizers, has triggered scientific interest towards the evaluation of organic fertilizers based on locally available resources, including crop residues, animal manure and green manures (Reijntjes, Haverkrot, \&Waters-Bayer, 1992). Focus on soil fertility research has shifted towards the combined application of organic matter and mineral fertilizers as a way to arrest the on going soil fertility decline in sub Saharan Africa (Vanlauwe, Wendt, \& Diels, 2001c). The organic sources can reduce the dependency on costly fertilizers by providing nutrients that are either prevented from being lost (recycling) or more truly added to the system (biological $\mathrm{N}$-fixation). When applied repeatedly, the organic matter leads to build-up of soil organic matter, thus providing a capital of nutrients that are slowly released (Giller et al., 1997) and at the same time increasing the soils buffering capacity for water, cations and acidity (de Ridder \& van Keulen, 1990).

Animal manure (called manure) according to Defoer, Budelman, Toulmin and Carter (2000) is an organic fertilizer consisting of partly decomposed mixture of dung and urine. Manure is recognized as a key resource in sustaining soil fertility in the tropics, supplying the soil with a range of macro- and micro- nutrients and organic matter. According to Camberato, Lippert, Chastain, and Plank (1996) and Fulhage (2000) the nutrients content of manure varies widely with animal species, age, ration quality and feed consumption, as well as with different methods of storage, handling methods, housing type, temperature and moisture content, treatment and land application. The beneficial role of animal manure in crop production has long been recognized (Schlecht, Mahler, Sangare, Susenbth, \& Becker, 1995; Karanja, Kapkiyai, Bunyasi, \& Murage, 1997; Harris, Lyord, Hofni-Collins, Barrett, \& Brown, 1997). The utilization of cattle manure as a soil amendment is an integral part of the Nigerian guinea savanna farmers (Harris \& Yusuf, 2001; Iwuafor et al., 2002). However, the information that is lacking to most of the farmers is the methods of manure management practices for optimal quality before field application and time of application of animal manure for optimum crop production. Also, Iwuafor et al. (2002) observed that, the results of trials conducted in the northern guinea savanna showed the need to investigate the high variability in manure quality across different farmers/sites, and to look for ways to avoid losses during manure storage, or at least to establish ranges of $\mathrm{N}$ contents for manures with different origins and storage methods. Therefore, the objectives of this study are to determine the effects of cow dung subjected to different management practices and Urea fertilizer on maize grain yield in the Northern Guinea Savanna of Nigeria.

\section{Materials and Methods}

\subsection{Location and Description of Experimental Site}

The field studies were carried out at Samaru at two different locations within the same zone at the IAR Research Farms and the Samaru College of Agriculture (SCA) Farm, Samaru, which are both located at Latitude $11^{\circ} 11^{\prime} \mathrm{N}$ and Longitude $7^{\circ} 33^{\prime} \mathrm{E}$ in the Northern Guinea Savanna zone of Nigeria.

Samaru has mean annual rainfall of about $1050 \mathrm{~mm}$, spanning the periods from May to September, while the dry season starts from October to April with a mean daily temperature of $24^{\circ} \mathrm{C}$ (Kowal \& Knabe, 1972). The hottest months are those that precede the rains (March to April) and coldest months occur in November to January, October and February are considered as transition months. The global radiation is evenly distributed throughout the year, ranging from $440 \mathrm{cal} . \mathrm{cm}^{2}$ day $^{-1}$ in August to $550 \mathrm{cal}^{\mathrm{cm}} \mathrm{cm}^{2} \mathrm{day}^{-1}$ in April to May (Kowal, 1972).

\subsection{Cow Dung Collection and Subjected to Management Practices}

The study consisted of collection and incubation of cow dung and subsequent evaluation using field experiments. The cow dung that was used for these experiments were collected from the National Animal Production Research Institute (NAPRI), Shika-Zaria in years 2003 and 2004. The cow dung collected was subjected to different management practices as described in Figure 1.

Fresh cow dung was collected early in the morning from pens and piled into a heap. The cow dung was then mixed thoroughly with a shovel with the aim of harmonizing it. After mixing it thoroughly, it was then subjected to the various management schedules as follows: (i) cow dung placed in a pit of $2 \times 2 \mathrm{~m}$ and $75 \mathrm{~cm}$ deep and covered (PC) with a polythene sheet, (ii) cow dung heaped on the ground surface and covered (SHC) with a polythene sheet, and (iii) cow dung heaped on the ground surface and left uncovered (SHU). The collection of the cow dung and its distribution to the 3 different management practices was repeated for the next 2-3 days as described above until enough cow dung was gathered. The cow dung was then allowed to decompose for four weeks (one month, composting) without any disturbance before it was removed and stored in the field. 
This experiment started in February, 2003 with the collection of cow dung and allowing it to decompose (composting) for 4 weeks which means the field storage (exposure) of the cow dung was from March to May (12 weeks of field storage before application to the soil as amendment). The same cow dung treatment as described for February above was repeated in March against April to May ( 8 weeks of field storage before application to the soil as amendment), April against May (4 weeks of field storage before application to the soil as amendment) and May against June ( 0 week) where cow dung was collected at the termination of composting and applied to the field immediately, without field storage (the moisture content was taken into consideration). The same procedure was repeated in the second year (2004).

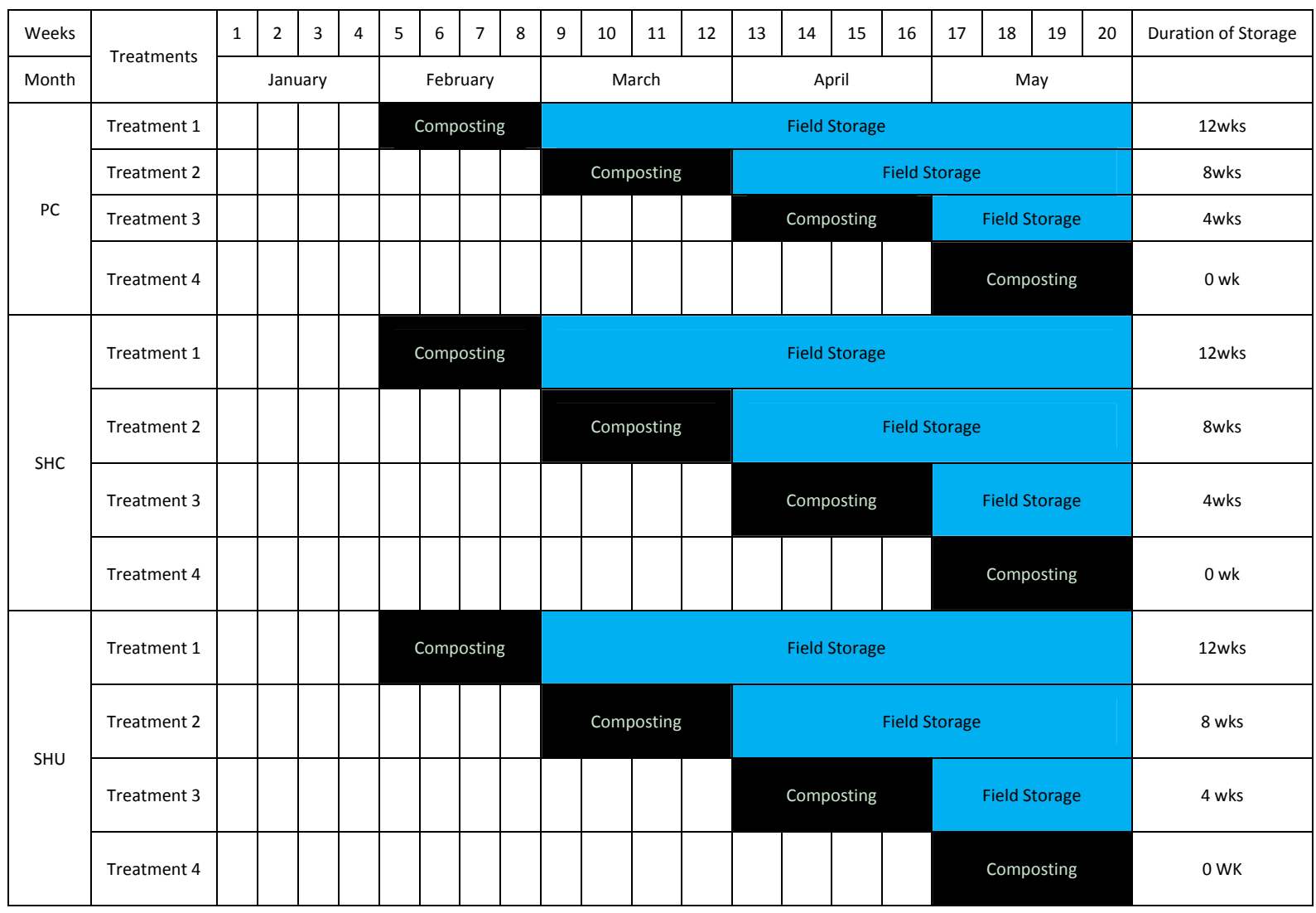

Figure 1. Diagrammatic presentation of experimental set up

\subsection{Cow Dung and Soil Sampling and Preparation}

Cow dung samples were taken after subjecting the cow dung to the three different management practices i.e. (PC, SHC and SHU) but before taking them to the field for storage. This set of cow dung after collection was air dried and stored for analysis. The second sampling of the cow dung was done at the end of field storage, before application and incorporation into the soil in the field (at this stage, the cow dung treatments must have been exposed at the field in storage after the 1 month of composting for different time durations of 12 weeks, 8 weeks, 4 weeks and 0 week). These were all carefully processed and kept for analysis and for use in the field.

Before the commencement of the experiment surface soil sample ( 0 to $20 \mathrm{~cm}$ depth) was collected from the field where the field experiment was conducted at IAR and SCA farms. The soil was air-dried and sieved to pass through the $2 \mathrm{~mm}$ sieve and kept for analysis.

\subsection{Cow Dung and Soil Analysis}

The surface soil samples for field studies were analyzed by the following methods: particle size distribution using

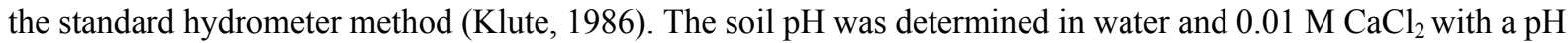
glass electrode using a soil: solution ratio of $1: 2.5$. Organic Carbon was determined by wet oxidation method of Walkley-Black (Nelson \& Sommers, 1982). 
Exchangeable bases were determined by extraction with neutral $1 \mathrm{~N} \mathrm{NH}_{4} \mathrm{O}$ AC saturation method. Potassium and Sodium in the extract were determined by the flame photometer, while $\mathrm{Ca}$ and $\mathrm{Mg}$ were determined by atomic absorption spectrophotometer (Juo, 1979). Available P was extracted by the Bray 1 method. The P concentration in the extract was determined colorimetrically using the spectronic 70 spectrophotometer. Total $\mathrm{N}$ was determined by the Kjeldahl procedure (Bremner \& Mulvaney, 1982; Bremner, 1982).

\subsection{Field Experiments}

The field experiments were conducted at two locations. The first trial was carried out at the IAR Farm, Samaru in the year 2003 season. The second trial was established at the SCA Farm, Samaru in 2004 season. In all the experiments, the same treatment combinations, experimental design, observations and procedures were maintained.

The experiment was a factorial experiment with 3 factors, laid out in a randomized complete block design replicated three times. The treatments were: 3 cow dung management practices, 4 different storage times after 1 month incubation (composting) before application to the field, 2 levels of $\mathrm{N}(3 \times 4 \times 2)$. There was a control treatment where no cow dung or nitrogen fertilizer was applied. These gave a total of 25 treatment combinations.

The land was plowed and harrowed and the field was mapped out into plots in the first year of the experiment. The plot sizes were $4 \times 5 \mathrm{~m}\left(20 \mathrm{~m}^{2}\right)$ and each plot was separated from the other by one meter. The plots were then immediately ridged manually at $75 \mathrm{~cm}$ between ridges with the hand hoe to incorporate the cow dung. Cow dung subjected to different management practices which had been conveyed and stored in the field at different times (March for 12 weeks, April for 8 weeks, May for 4 weeks and June for 0 week) were applied manually at $5.0 \mathrm{tha}^{-1}$ on dry matter weight basis.

In both years of the experimentation, maize (Var. Oba super II) dressed with Fernasand D was sown at two seeds per hole, at a spacing of $25 \mathrm{~cm}$ within the row. The seedlings were later thinned to one plant per hill at two weeks after planting.

A blanket application of $\mathrm{P}$ was applied as single super phosphate (SSP) at the rate of $60 \mathrm{~kg} \mathrm{P}_{2} \mathrm{O}_{5} \mathrm{ha}^{-1}$ and at $45 \mathrm{~kg} \mathrm{~N}$ $\mathrm{ha}^{-1}$ as urea was applied in two split equal doses to the appropriate plots. The first application was done immediately after the first weeding ( 3 WAP). The second dose was applied at the time of second weeding (6 WAP). In each case the fertilizer was applied by single band about $5 \mathrm{~cm}$ deep, made along the ridge, $5-8 \mathrm{~cm}$ away from the plant stand and covered immediately.

The weeding operation was carried out at the third and sixth weeks after planting. Remolding was carried out at 8-9 WAP to ensure proper weed control and a clean field at the time of harvesting.

The net plots (four inner rows) were harvested when the crop was fully matured and dry. Ears for each net plot were de-husked and the fresh weight of the cobs was taken immediately. After sun drying, the cobs were shelled using the manual Sheller. The dry grain weight for each treatment was recorded.

\subsection{Statistical Analysis}

The data collected from the field studies were subjected to analysis of variance (ANOVA) using the SAS package (SAS Inst., 1999). Significant means were separated using the Duncan's Multiple Range Test (DMRT) at 5\% level of probability.

\section{Results and Discussion}

Some selected physical and chemical properties of the two sites are shown in Table 1, while the NPK content of the cow dung used in the field experiments are presented in Table 2. 
Table 1. Some physical and chemical properties of the soil of the first and second experimental sites at commencement of study

\begin{tabular}{lcc}
\hline Parameters & IAR Farm & SCA Farm \\
\hline Sand $\left(\mathrm{g} \mathrm{kg}^{-1}\right)$ & 640 & 360 \\
$\mathrm{Silt}\left(\mathrm{g} \mathrm{kg}^{-1}\right)$ & 210 & 540 \\
Clay $\left(\mathrm{g} \mathrm{kg}^{-1}\right)$ & 150 & 100 \\
Texture & Sandy loam & Silt loam \\
pH 1:2.5 $\left(\mathrm{H}_{2} \mathrm{O}\right)$ & 5.90 & 5.90 \\
$\mathrm{pH} 1: 2.5\left(\mathrm{CaCl}_{2}\right)$ & 5.10 & 5.20 \\
Organic Carbon $\left(\mathrm{g} \mathrm{kg}^{-1}\right)$ & 7.40 & 4.40 \\
Total N $\left(\mathrm{g} \mathrm{kg}^{-1}\right)$ & 0.53 & 0.70 \\
$\mathrm{C} / \mathrm{N} \mathrm{ratio}$ & 14.00 & 6.29 \\
Bray $1 \mathrm{P}\left(\mathrm{mg} \mathrm{kg}^{-1}\right)$ & 7.00 & 2.00 \\
Exchangeable Calcium $\left(\mathrm{cmol} \mathrm{kg}^{-1}\right)$ & 2.00 & 1.60 \\
Exchangeable Magnesium $\left(\mathrm{cmol} \mathrm{kg}^{-1}\right)$ & 0.80 & 1.00 \\
Exchangeable Potassium $\left(\mathrm{cmol} \mathrm{kg}^{-1}\right)$ & 1.84 & 0.49 \\
Exchangeable Sodium $\left(\mathrm{cmol} \mathrm{kg}^{-1}\right)$ & 1.87 & 1.13 \\
\hline
\end{tabular}

$\mathrm{IAR}=$ Institute for Agricultural Research; SCA = Samaru College of Agriculture.

Table 2. Total NPK content of cow dung used for greenhouse and field studies

\begin{tabular}{|c|c|c|c|c|c|c|c|c|c|c|c|c|c|}
\hline \multirow{3}{*}{$\begin{array}{l}\text { Management } \\
\text { practices (one month } \\
\text { incubation) }\end{array}$} & \multirow{3}{*}{$\begin{array}{l}\text { Time of manure } \\
\text { exposure in the field } \\
\text { before use (weeks) }\end{array}$} & \multicolumn{6}{|c|}{2003 SEASON } & \multicolumn{6}{|c|}{2004 SEASON } \\
\hline & & \multicolumn{2}{|c|}{ N (\%) } & \multicolumn{2}{|c|}{$\mathrm{P}(\%)$} & \multicolumn{2}{|c|}{$\mathrm{K}(\%)$} & \multicolumn{2}{|c|}{ N (\%) } & \multicolumn{2}{|c|}{$\mathrm{P}(\%)$} & \multicolumn{2}{|c|}{$\mathrm{K}(\%)$} \\
\hline & & $\mathrm{a}$ & $\mathrm{b}$ & $\mathrm{a}$ & $\mathrm{b}$ & $\mathrm{a}$ & $\mathrm{b}$ & $\mathrm{a}$ & $\mathrm{b}$ & $\mathrm{a}$ & $\mathrm{b}$ & $\mathrm{a}$ & $\mathrm{b}$ \\
\hline SHUM & 12 & 1.05 & 1.40 & 0.75 & 0.25 & 5.48 & 1.65 & 0.88 & 1.00 & 0.67 & 0.64 & 3.60 & 2.78 \\
\hline SHUA & 8 & 1.40 & 1.40 & 0.39 & 0.39 & 1.43 & 1.65 & 1.23 & 1.08 & 0.60 & 0.67 & 3.30 & 3.08 \\
\hline SHUY & 4 & 1.40 & 1.58 & 0.60 & 0.50 & 1.35 & 1.35 & 1.23 & 1.20 & 0.60 & 0.91 & 2.55 & 6.08 \\
\hline SHUJ & 0 & 1.75 & 1.75 & 0.53 & 0.75 & 1.25 & 2.25 & 1.20 & 1.23 & 0.67 & 0.71 & 3.68 & 2.63 \\
\hline SHCM & 12 & 1.23 & 1.40 & 0.75 & 0.67 & 1.35 & 1.75 & 1.05 & 1.08 & 0.39 & 0.51 & 1.73 & 2.10 \\
\hline SHCA & 8 & 1.40 & 1.05 & 0.83 & 0.39 & 1.50 & 1.28 & 1.23 & 1.10 & 0.46 & 0.60 & 0.98 & 4.65 \\
\hline SHCY & 4 & 1.23 & 1.23 & 0.67 & 0.32 & 1.65 & 1.43 & 1.23 & 1.58 & 0.53 & 0.71 & 1.88 & 3.53 \\
\hline SHCJ & 0 & 2.10 & 1.93 & 0.91 & 0.75 & 1.50 & 3.08 & 1.23 & 1.25 & 0.53 & 0.60 & 0.98 & 2.55 \\
\hline PCM & 12 & 1.75 & 1.45 & 0.79 & 0.39 & 3.15 & 1.98 & 1.05 & 1.05 & 0.80 & 0.60 & 4.88 & 1.58 \\
\hline PCA & 8 & 1.75 & 1.05 & 0.60 & 0.32 & 5.25 & 1.20 & 1.58 & 1.58 & 0.53 & 0.53 & 4.28 & 1.80 \\
\hline PCY & 4 & 1.58 & 1.75 & 0.67 & 0.49 & 3.68 & 1.58 & 1.98 & 1.05 & 0.53 & 0.71 & 3.15 & 2.63 \\
\hline PCJ & 0 & 1.75 & 1.58 & 0.83 & 0.53 & 4.28 & 1.58 & 1.70 & 1.70 & 0.58 & 0.53 & 3.60 & 1.73 \\
\hline CONTROL & - & 1.58 & & 0.75 & & 1.65 & & 1.55 & & 0.73 & & 1.50 & \\
\hline
\end{tabular}

$\mathrm{a}=$ At termination of 1 month incubation; $\mathrm{b}=$ At time of application for field trial.

SHUM $=$ Surface heaped uncovered March

$\mathrm{PCM}=$ Pit covered March

SHCA $=$ Surface heaped covered April

SHUY $=$ Surface heaped uncovered May

$\mathrm{PCY}=$ Pit covered May

SHCJ $=$ Surface heaped covered June PCJ $=$ Pit

covered June
SHCM $=$ Surface heaped covered March

SHUA $=$ Surface heaped uncovered April

PCA $=$ Pit covered April

SHCY $=$ Surface heaped covered May

SHUJ $=$ Surface heaped uncovered June 


\subsection{Maize Grain Yields}

The effects of cow dung management practices, duration of storage before field application and $\mathrm{N}$ levels on maize grain yield for 2003 and 2004 seasons are shown in Table 3. There were significant $(\mathrm{P}<0.05)$ differences among the treatments in the two farms. Results of treatments were consistent for the two years e.g. all the $\mathrm{N}$ amended treatments $(+\mathrm{N})$ consistently gave higher maize grain yield values than the zero $\mathrm{N}$ amended $(\mathrm{oN})$ treatments. The values for the control also consistently gave lower values compared to the $\mathrm{N}$ amended treatments. Where treatments were amended with nitrogen, the surface heaped covered April treatment (SHCA) consistently gave higher maize grain yields in the two years. Among treatments that were not amended with $\mathrm{N}$, the surface heaped uncovered May (SHUY) gave higher grain yields in the two years (farms).

Table 3. Effects of manure management practices, time of application and nitrogen levels on maize grain yield $(\mathrm{kg}$ $\mathrm{ha}^{-1}$ ) in IAR and SCA farms

\begin{tabular}{|c|c|c|c|c|}
\hline \multirow{3}{*}{ Treatments } & \multirow{2}{*}{\multicolumn{2}{|c|}{$\begin{array}{c}\text { IAR farm } \\
2003\end{array}$}} & \multicolumn{2}{|c|}{ SCA farm } \\
\hline & & & \multirow[b]{2}{*}{ oN } & 2004 \\
\hline & $\mathrm{oN}$ & $+\mathrm{N}$ & & $+\mathrm{N}$ \\
\hline \multicolumn{5}{|l|}{$\begin{array}{l}\text { SHU } \\
\end{array}$} \\
\hline SHUM & $1120.8 \mathrm{c}-\mathrm{f}$ & $1925.0 \mathrm{a}-\mathrm{e}$ & $241.7 \mathrm{i}$ & $1308.3 \mathrm{c}-\mathrm{g}$ \\
\hline SHUA & $904.2 \mathrm{ef}$ & $2341.7 \mathrm{ab}$ & $500.0 \mathrm{hi}$ & $2158.3 \mathrm{ab}$ \\
\hline SHUY & $1645.8 \mathrm{a}-\mathrm{e}$ & 2195.8abc & 800.0e-i & $1633.3 \mathrm{a}-\mathrm{d}$ \\
\hline SHUJ & $1341.7 b-f$ & 1966.7a-e & $225.0 \mathrm{i}$ & $1083.3 \mathrm{~d}-\mathrm{h}$ \\
\hline \multicolumn{5}{|l|}{ SHC } \\
\hline SHCM & $959.2 \mathrm{def}$ & 1629.2a-e & $243.3 \mathrm{i}$ & $1316.7 \mathrm{c}-\mathrm{g}$ \\
\hline SHCA & $1270.8 \mathrm{~b}-\mathrm{f}$ & $2545.8 \mathrm{a}$ & 691.7f-i & $2308.3 \mathrm{a}$ \\
\hline SHCY & $1312.5 b-f$ & 1987.5a-e & 441.7hi & $1466.7 \mathrm{~b}-\mathrm{e}$ \\
\hline SHCJ & $1395.8 \mathrm{a}-\mathrm{e}$ & 1875.0a-e & $525.0 \mathrm{hi}$ & $1050.0 \mathrm{~d}-\mathrm{h}$ \\
\hline \multicolumn{5}{|l|}{$\mathrm{PC}$} \\
\hline PCM & $1079.2 \mathrm{c}-\mathrm{f}$ & 2090.8a-e & 508.3hi & $1950.0 \mathrm{abc}$ \\
\hline PCA & $1412.5 \mathrm{a}-\mathrm{e}$ & $2112.5 \mathrm{a}-\mathrm{e}$ & $766.7 \mathrm{e}-\mathrm{i}$ & $1766.7 \mathrm{a}-\mathrm{d}$ \\
\hline PCY & $1387.5 \mathrm{a}-\mathrm{e}$ & $2120.8 \mathrm{a}-\mathrm{d}$ & $608.3 \mathrm{ghi}$ & $1416.7 \mathrm{c}-\mathrm{f}$ \\
\hline PCJ & $1345.8 b-f$ & 1904.2a-e & $208.3 \mathrm{i}$ & $1108.3 \mathrm{~d}-\mathrm{h}$ \\
\hline Control & $211.7 \mathrm{f}$ & & 275.li & \\
\hline $\mathrm{SE}+$ & 348.65 & & 230.96 & \\
\hline
\end{tabular}

Means with the same letter(s) within the same group are not significantly different at 5\% level of significance

SHUM $=$ Surface heaped uncovered March,

$\mathrm{PCM}=$ Pit covered March,

SHCA $=$ Surface heaped covered April,

SHUY $=$ Surface heaped uncovered May

$\mathrm{PCY}=$ Pit covered May

SHCJ $=$ Surface heaped covered June
SHCM $=$ Surface heaped covered March,

SHUA $=$ Surface heaped uncovered April,

PCA $=$ Pit covered April,

SHCY $=$ Surface heaped covered May

SHUJ $=$ Surface heaped uncovered June

$\mathrm{PCJ}=$ Pit covered June

$\mathrm{oN}=$ Direct evaluation (non $\mathrm{N}$ amended), $+\mathrm{N}=45 \mathrm{~kg} \mathrm{~N}^{-1}$ ( $\mathrm{N}$ amended).

But looking at the nutrient content of the cow dung used in Table 2, particularly the $\mathrm{N}$ content; it was expected that the June treatments which had the highest $\mathrm{N}$ content irrespective of the management practice at the time of application of cow dung to the field to give the highest grain yield. This was not so probably because of the nature of the nutrient release pattern, which did not coincide with the period of highest nutrient demand by the maize crop 
to produce the optimum grain yield. The management practices must have enhanced nutrient availability with the period of highest nutrient demand by the maize crop through the incubation process which must have enhanced nutrient availability to coincide with the period of highest nutrient demand by the maize crop at the SHCA treatment that gave the highest grain yield. Many scientists have advanced reasons why such discrepancies in the manure do exist. Myers, Palm, Guevas, Gunatilleke and Brossard (1994) reported that good manure should synchronize mineral nitrogen release and plant demand such that the peak mineral nitrogen release coincides with peak plant biomass development and hence peak nitrogen requirements. Also, Lekasi, Ndung'u and Kifuko (2005) reported that it is advantageous if the organic materials added to the soil mineralize nutrients slowly and the rate of nutrient mineralization increased as the plant growth progressed. He further explained that, good soil releases adequate nutrients for optimum plant growth as they mature. Closer synchronization of nutrients demand ensures efficient utilization of organic inputs applied to the soil, he added. In other words, high content of nutrients in the cow dung was not an indication for high performance in crop production. Organic materials that mineralize too readily, subject mineralized nutrients to losses through processes such as leaching and volatilization on the other hand, organic materials that releases nutrients later in the season will not benefit the plant or crop as it would have matured with inadequate availability of nutrients during the critical growing stages. The overall amounts of nutrients released from organic amendments for crop uptake depends on the quality, the rate of application, the nutrient release pattern and the environmental conditions (Mugwira \& Mukurumbira, 1986; Murwira \& Kirchmann, 1993).

All the $\mathrm{N}$ amended treatments gave significantly $(\mathrm{P}<0.05)$ higher grain yields than the control treatment, while most of the non $\mathrm{N}$ amended treatments were statistically at par with the control treatment. This showed that, the application of cow dung alone that have been subjected to different management practices, was not enough to give a significant difference on maize grain yield. This agreed with the work of Uyovbisere and Elemo (2002) who stated that organic matter cannot be used alone, but with some level of inorganic fertilizer. It has been recognized that the combined application of organic matter and inorganic fertilizer is required to increase crop production and arrest soil nutrient depletion in West Africa (FAO, 1999; Giller, 2002; Iwuafor et al., 2002). Tanimu, Iwuafor, Odunze and Tian (2007) reported higher doses of $\mathrm{N}$ fertilizers increased grain yield and yield related components of maize.

\section{Conclusion}

Based on the results of this study, the surface heaped covered April (SHCA). N amended treatment consistently gave the highest maize grain yield in the two farms than all other treatments. The non $\mathrm{N}$ amended treatments was not able to significantly increase the maize grain yields than the untreated control. It is therefore concluded that for high maize productivity in this zone the surface heaped covered April treatment, amended with $\mathrm{N}$ at $45 \mathrm{~kg} \mathrm{~N}^{-1}$ is recommended for use.

\section{References}

Bremner, J. M. (1982). Total nitrogen. In C. A. Black (Ed.), Methods of Soil Analysis Part II. Chemical and Microbiological Properties (pp. 1149-1178). Am. Soc. of Agron. Madison Wisconsin.

Bremner, J. S., \& Mulvaney, C. S. (1982). Nitrogen-total. In A. L. Page (Ed.), Methods of Soil Analysis, Part 2. American Society of Agronomy (pp. 595-624). Madison, Wisconsin.

Camberato, J., Lippert, B., Chastain, J., \& Plank, O. (1996). Land application of Manure. Retrieved from http:/hubcap.clemson.edu/ blpprt/manure.html

De Ridder, N., \& van Kuelen, H. (1990). Some aspects of the role of organic matter in sustainable intensified arable farming systems in the west African semi-arid tropics (SAT). Fertilizer Research, 26, 299-310. http://dx.doi.org/10.1007/BF01048768

Defoer, T., Budelman, A., Toulmin, C., \& Carter, S. E. (2000). Managing soil fertility in the tropics. In T. Defoer, \& A. Budelman (Eds.), Building common knowledge. Participatory learning and action research (Part 1). A research guide for participatory learning and action research. Amsterdam, The Netherlands : Royal Tropical Institute.

Ewenzor, W. O., Udo. E. J., Osoroh, N. J., Ayotade, K. A., Adepetu, J. A., Chude, V., \& Udegbe, O. (1989). Fertilizer use and management practices in Nigeria. Federal Ministry of Agriculture and Natural Resources and Rural development.

F.A.O. (1986). Sustainable Agricultural Production implication for International Agricultural Research. FAO Research and Technical Paper, No. 4 Rome Italy. 
F.A.O. (1997). Report on technical assistance related to the Uruguay Round Table Committee on Commodity Problems, $62^{\text {nd }}$ Session, January 12-15, Rome Italy.

F.A.O. (1999). Soil fertility initiative for sub-Saharan Africa. Proc. SFI/FAO consultation, Rome. 19-20 Nov. 1999. FAO, Rome.

Federal Ministry of Agriculture (FMA). (2005). Annual Report, Federal Ministry of Agriculture and Natural Resources, Abuja. In C. D. Fulhage (Ed.), Reduce environmental problems with proper land application of animal manure. University of Missouri Extension. USA.

Giller, K. E. (2002). Targeting management of organic resources and mineral fertilizers: Can we match scientists' fantasies with farmers' realities? In B. Vanlauwe, J. Diels, N. Saginga, \& R. Merckx (Eds), Integrated plant nutrient management in Sub-saharan Africa (pp. 155-171). From concept to practice. Wallingford, Oxon, UK: CAB International.

Giller, K. E., Cadisch, G., Ehaliotis, C., Adams, E., Sakala, W. D., \& Mafongoya, P. M. (1997). Building soil nitrogen capital in Africa. In R. J. Buresh, P. A. Sanchez, \& F. Calhoun (Eds), Replenishing soil fertility in Africa (pp. 151-192). Soil Science Society of America Special Publication No. 51. Soil Science Society of America, Madison, Wisconsin, USA. Proceedings of an International Symposium, Indianapolis, USA. $6^{\text {th }}$ Nov. 1996.

Harris, F., \& Yusuf, M. A. (2001). Manure management by smallholder farmers in the Kano close-settled zone, Nigeria. Experimental Agriculture, 37, 319-332. http://dx.doi.org/10.1017/S0014479701003040

Harris, P. J. C., Lloyd, H. D., Hofny-Collins, A. H., Barrett, H. R., \& Browne, A. W. (1997). Organic Agriculture in Sub-saharan Africa: Farmer Demand and Potential Development, a study information policy. ODA Project R632A. Henry Doubleday Research Association, Coventry and African Studies Center, Coventry University, UK.

Heathcote, R. G. (1970). Soil fertility under continuous cultivation in northern Nigeria.1: The role of organic manures. Experimental Agric., 6, 229-237. http://dx.doi.org/10.1017/S0014479700009376

IFPRI. (1995). A 2020 Vision for Food Agriculture and Environment in Sub-saharan Africa. Discussion paper 4. In O. Badiane, \& C. Delgado. (Eds), International Food Policy Research Institute (IFPRI). Washington DC, USA.

Iwuafor, E. N. O., Aihou, K., Jaryum, J. S., Vanlauwe, B., Diels, J., Saginga, N., ... Merckx, R. (2002). On-farm evaluation of contribution of sole and mixed applications of organic matter and Urea to Maize grain production in the Savanna. In B. Vanlauwe, J. Diels, N. Saginga, \& R. Merckx (Eds), Integrated plant nutrient management in Sub-saharan Africa (pp. 185-197). Wallingford, Oxon, UK: CAB International.

Jabbar, M. A. (1996). Energy and the Evolution of Farm systems- the potentials mixed farming in the moist Savanna of Sub-saharan Africa. Out look on Agriculture, 25, 27-36.

Jones, M. J., \& Stockinger, K. R. (1976). Effect of fertilizer on exchangeable cation ratios and crop nutrition in northern Nigeria. Experimental Agric., 12, 49-59.

Jones, M. J., \& Wild, A. (1975). Soils of West African Savanna. Comm. No. 55. http://dx.doi.org/10.1017/S0014479700007055

Juo, A. R. S. (1979). Selected methods for soil and plant analysis. IITA Manual Series. No. 1, Ibadan, Nigeria.

Kang, B. T., \& Duguma, B. (1985). Nitrogen management in alley cropping systems. In B. T. Kang, \& J. Van der Heide (Eds), Nitrogen Management in Farming Systems in the Humid and Subhumid Tropics (pp. 269-264). Institute for Soil Fertility (IB) Haren, The Netherlands and International Institute of Tropical Agriculture (IITA), Ibadan, Nigeria.

Kang, B. T., \& Wilson, G. F. (1987). The development of Alley cropping as a promising Agro-forestry Technology. In H. A. Steppter, \& P. K. R. Nair (Eds.), Agro-forestry: A decade of Devt., Nairobi, Kenya. ICRAF.

Kang, B. T., Van, D., Kruys, A. C. B., \& Cooper, D. C. (1986). Alley cropping for food crop production in the Humid and Hub-humid Tropics. In B. T. Kang, \& L. Reynolds (Eds.), Alley farming in the Humid and Sub-humid Tropics. Ottawa Canada, IORC: Proc. Of International workshop.

Karanja, N., Woomer, P., Kapkiyai, J., Bunyasi, S., \& Murage, E. W. (1997). Agriculture Resource Management in Smallholder Systems in the Central Kenyan Highlands. Technical Report and Financial Statement. Rockefeller Foundation Forum for Agricultural Research Husbandry. 
Klute, A. (1986). Methods of Soil Analysis (2nd ed.). Madison, Wisconsin: American Society of Agronomy.

Kowal, J. M. (1972). Radiation and Potential crop protection in Samaru, Nigeria. Savanna, 1, 89-101.

Kowal, J. M., \& Knabe, D. T. (1972). An Agro-Climatological Atlas of Northern Nigeria with explanatory notes. Ahmadu Bello University: Zaria Press.

Lekasi, J. K., Ndung'u, K. W., \& Kifuko, M. N. (2005). Organic Resource Management in Kenya. Perspective and Guidelines. Forum for organic resource management and Agricultural Technologies (FORMAT).

McIntire, J., Bourzart, D., \& Pingali, P. (1992). Crop-livestock Interaction in Sub-Saharan Africa. Washington, DC, USA: World Bank.

Mugwira, L. M., \& Mukumbira, L. M. (1986). Nutrient supply power of different groups of manure from the communal areas and commercial feedlots. Zimbabwe Agricultural Journal, 83, 25-29.

Murwira, H. K., \& Kirchmann, H. (1993). Nitrogen dynamics and maize growth in Zimbabwean sandy soils under manure fertilization. Communication in Soil Science and Plant Analysis, 24, 2343-2359. http://dx.doi.org/10.1080/00103629309368960

Myers, R. J. K., Palm, C. A., Cuevas, E., Gunatilleke, I. U. N., \& Brossard, M. (1994). The synchronisation of nutrient mineralisation and plant nutrient demand. In P. L. Woomer, \& M. J. Swift (Eds.), The Biological Management of Tropical Soil Fertility. New York, USA: John Wiley and Sons.

Nelson, D. W., \& Sommers, L. E. (1982). Total carbon, organic carbon and organic matter. In A. L. Page, R. H. Miller, \& D. R. Keeney (Eds.), Methods of Soil Analysis No. 9, Part 2, Chemical and Microbiological properties (pp. 539-579). Madison, Wisconsin: Am. Soc. Agron..

Ojanuga, A. G. (1979). Clay Mineralogy of Nigerian Soils I. The Nigerian tropical savanna regions. Soil Sci. Soc. Am. J., 43, 1237-1242. http://dx.doi.org/10.2136/sssaj1979.03615995004300060038x

Okoruwa, A. F., \& Kling, J. G. (1996). Nutrition and Quality of Maize. IITA Research Guide 33.

Reijntjes, C., Haverkrot, B., \& Waters-Bayer, A. (1992). Farming for the future. An Introduction to Low External Input and Sustainable Agriculture. London, UK: Macmillan Press.

SAS Institute. (1999). SAS User's Guide. Cary, N.C.: SAS Inst.

Schlecht, E., Mahler, F., Sangare, M., Susenbth, A., \& Becker, K. (1995). Quantitative and qualitative estimation of nutrient intake and feacal excretion of Zebu cattle grazing natural pasture in semi-arid Mali. In J. M. Powell, S. Fernandez-Rivera, T. O. Williams, \& C. Renard (Eds.), Livestock and sustainable nutrient cycling in mixed farming systems of Sub-saharan Africa. Volume II: Technical papers. Addis Ababa, Ethiopia: International Livestock Center for Africa (ILCA).

Tanimu, J., Iwuafor, E. N. O., Odunze, A. C., \& Tian, G. (2007). Effect of incorporation of leguminous cover crops on yield and yield components of Maize. World Journal of Agricultural Sciences, 3(2), 243-249.

Tarfa, B. D., Kureh, I., Kuchinda, N. C., Shinggu, A., Omolehin, R., Alabi, S. A., \& Ado, S. (2003). Influence of initial Soil Physico-chemical properties on striga and maize crop parameters under improved management practices. In B. Badu-Apraku, M. A. B. Fakorede, M. Ouedraogo, R. J. Carsky, \& M. Menkir (Eds.), Proceedings of international workshop on maize Revolution I West and Central African held at IITA Cotonou, Benin republic on 14-18 May, 2001.

Uyovbisere, E. O., \& Elemo, K. A. (2002). Effect of foliage of locust bean (Parkia biglobosa) and neem (Azadirachta indica) on soil fertility and productivity of early maize in a savanna Alfisol. In B. Badu-Apraku, M. A. S. Fakorede, M. Ouedraogo, \& R. J. Carsky (Eds.), Impact, challenges and prospects of maize research and development in West and Central Africa (pp.185-194).

Vanlauwe, B., Wendt, J., \& Diels, J. (2001c). Combined application of organic matter and fertilizer. In G. Tian, F. Ishida, \& J. D. H. Keatinge (Eds), Sustaining Soil Fertility in West Africa (pp. 247-279). SSSA special publication No. 58, Soil Science Society of America, Madison, Wisconsin, USA.

Winrock. (1992). The pattern of soil fertility maintenance. In Assessment of Agriculture in sub-saharan Africa (pp. 72-102). Arkansas, USA: Winrock International. 